\title{
NEW RECORDS OF PREDATORY MITES OF THE GENUS STIGMAEUS (ACARI: PROSTIGMATA: STIGMAEIDAE) FROM WESTERN SIBERIA WITH THE REDESCRIPTIONS OF S. DIGNUS KUZNETSOV AND S. UZUNOLUKENSIS ÖZÇELIK AND DOĞAN
}

\author{
Alexander A. Khaustov \\ X-Bio Institute, Tyumen State University, Tyumen, Russia \\ e-mail: alex1973khaustov@gmail.com
}

\begin{abstract}
During a study of predatory mites of Western Siberia, I have recorded the following six species of the genus Stigmaeus (Acari: Stigmaeidae): S. dingus Kuznetsov; S. uzunolukensis Özçelik and Doğan; S. harsitensis Doğan, Doğan and Erman; S. fimus Doğan, Doğan and Erman; S. corticeus Kuznetsov; and S. pilatus Kuznetsov. These species were recorded for the first time from Asian Russia. Moreover, three of the six species-S. uzunolukensis, S. harsitensis and S. fimus-have been recorded for the first time from Russia as well. This article redescribes females of $S$. dingus and $S$. uzunolukensis based on materials from Western Siberia. Also, a $S$. uzunolukensis male is described for the first time.
\end{abstract}

KEY WORDS: Acarina, Raphignathoidea, systematics, morphology, Russia.

DOI: 10.21684/0132-8077-2020-28-2-177-191

\section{INTRODUCTION}

The mite family Stigmaeidae (Acari: Prostigmata) is the largest in the superfamily Raphignathoidea. It includes about 618 species of 33 valid genera (Doustaresharaf and Bagheri 2019; Doustaresharaf et al. 2019; Fan et al. 2019; Khan et al. 2019; Stathakis et al. 2019; Doğan and Doğan 2020; Doğan et al. 2020). Most stigmaeid mites are free-living predators of various small arthropods. Some species of Eustigmaeus feed on mosses, while several species of Stigmaeus and Eustigmaeus are parasites of sand flies (Diptera: Psychodidae). Species of the genera Zetzelia and Agistemus are probably the second most important group of plant mite predators after Phytoseiidae (Gerson et al. 2003). The genus Stigmaeus Koch, 1836 is the largest in the family: it includes about 154 species (Fan et al. 2019; Stathakis et al. 2019; Doğan and Doğan 2020).

At present, 24 species of the genus are known from Russia (Khaustov 2015, 2016). Nine species have been recorded from Western Siberia: $S$. tolstikovi Khaustov, 2015; S. mollibus Khaustov, 2016; S. livshitzi Kuznetsov, 1977; S. delaramae Khanjani, 2014; S. mitrofanovi Khaustov, 2014; S. silvestris Khaustov, 2014; S. purpurascens Summers, 1962; S. longipilis (Canestrini, 1889); and S. sphagneti (Hull, 1918) (Khaustov 2015, 2016; Khaustov and Abramov 2017). During my study of stigmaeid mites of Western Siberia, I have recorded six new species of the genus Stigmaeus. Two species-S. dingus and S. uzunolukensishave been redescribed based on materials from Western Siberia.

\section{MATERIALS AND METHODS}

Specimens, after being collected from various habitats using Berlese funnels, were mounted in Hoyer's medium. In the description below, the palpal, idiosomal and leg setations follow Grandjean $(1939,1944,1946)$. The nomenclature for the prodorsal setae follows that of Kethley (1990). The nomenclature for the idiosomal shields follows that of Summers (1962). All measurements are given in micrometres $(\mu \mathrm{m})$. In the descriptions of leg setations, the number of solenidia is given in parentheses. All examined materials are deposited in the mite collection of the Tyumen State University Museum of Zoology, Tyumen, Russia. Mite morphology was studied using a Carl Zeiss AxioImager A2 compound microscope with phase contrast and DIC objectives. Micrographs were taken with an AxioCam ICc5 digital camera.

\section{SYSTEMATICS}

Family Stigmaeidae Oudemans, 1931

Genus Stigmaeus Koch, 1836

Type species: Stigmaeus cruentus Koch, 1836, by subsequent designation by Berlese (1910).

\section{Stigmaeus dignus Kuznetsov, 1978}

$$
\text { (Figs. 1-5) }
$$

Stigmaeus dignus Kuznetsov, 1978, 691, Figs. 2, III.

Redescription. Female. Length of idiosoma 410-485, width 250-295.

Idiosomal dorsum (Figs. 1A, 5). Central shield with two pairs of setae $c l$ and $d l$; median zonal 

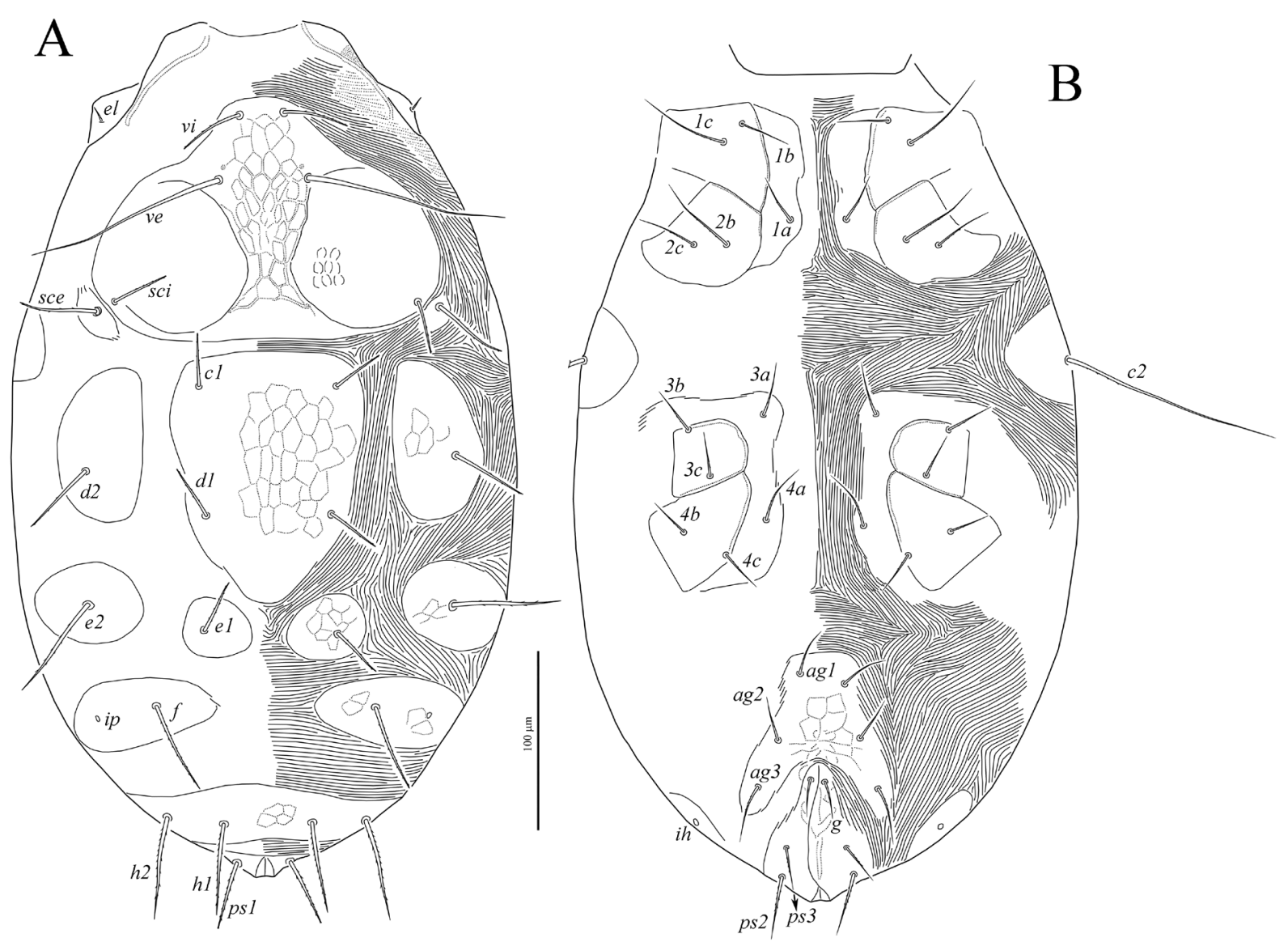

Fig. 1. Stigmaeus dingus Kuznetsov, 1978, female: A-dorsum of idiosoma; B-venter of idiosoma.

and intercalary shields paired. All shields with poorly sclerotized subcuticular reticulation without dorsal dimples. Postocular bodies very large, round, with very weak wavy microsculpture; distance between postocular bodies shorter than distance between bases of setae ve. Eyes absent. Striation anterolateral to prodorsal plate with microtubercles. Setae ve and $c 2$ pointed, smooth or with few very small barbs; other dorsal setae blunt-ended and sparsely barbed. Lateral parts of intercalary and suranal shields with clearly visible cupules ip and $i h$, respectively (Fig. 5B). Setae $e 2$ slightly or distinctly longer than $d 2$ (Figs. 5A, B). Setae $p s 1$ located dorsally. Length of dorsal setae: vi 38-41, ve 105-115, sci 28-33, sce 42-48, c1 30-31, c2 110-125, d1 31-33, d2 40-45, el 31-32, e2 59-78, f 48-53, h1 48-52, h2 53-58, psl 39-40.

Idiosomal venter (Fig. 1B). Aggenital plate with weak subcuticular reticulations, other plates without distinct reticulation. All ventral setae pointed, smooth or weakly barbed. Aggenital plate with three pairs of aggenital setae; one pair of genital setae. Length of ventral setae: $1 a 28-30,1 b$ 26-30, 1c 52-54, 2b 46-48, 2c 32-33, 3a 25-35,
$3 b 24-25,3 c$ 25-27, 4a 30-36, 4b 22-26, 4c 24-25, ag1 26-28, ag2 28-30, ag3 30-35, g 23-25, ps2 31-36, ps3 17-18.

Gnathosoma (Fig. 2). Tibial claw large, about as long as palptarsus. Setae $l$ ' on palpal tibia short spiniform. All setae of femur, genu and tibia pointed and weakly barbed; all setae of palptarsus smooth. Number of setae on palpal segments: $\operatorname{Tr} 0$, Fe 3 (d, l', v'), Ge 2 (d, l'), Ti 3 (d, l', l'), Ta 8(1) (fused eupathidia $u l$ ', $u l$ ", sul, eupathidion $a c m$, $b a, b p, l p, 1$ solenidion $\omega)$. Palpal supracoxal setae (ep) thin, almost setiform, with slightly rounded tip. Rostrum of subcapitulum (Fig. 2B) relatively long. All subcapitular setae pointed; or 2 smooth, other subcapitular setae weakly barbed. Basal part of subcapitulum without distinct reticulation, punctate. Lengths of subcapitular setae: $m$ 32-34, $n$ 28-32, or $128-29$, or 2 21-22. Length of cheliceral stylets 58-60.

Legs (Figs. 3, 4). All legs with one pair of welldeveloped claws. Empodial raylets with slightly widened tips. Leg segments without distinct reticulation. Leg I (Fig. 3A). Coxae I posterodorsally with short setiform leg supracoxal setae $(e l)$. 

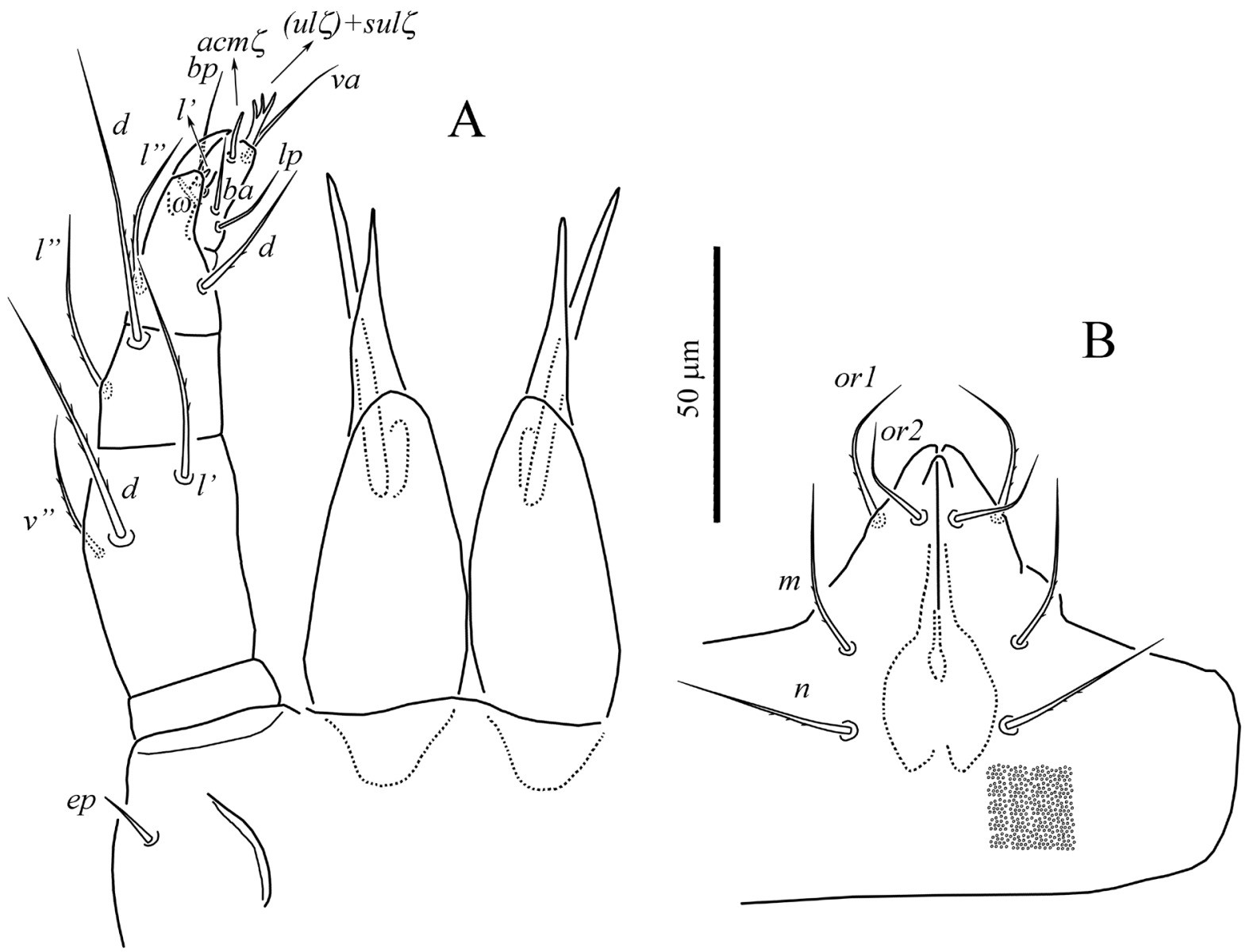

Fig. 2. Stigmaeus dingus Kuznetsov, 1978, female: A—gnathosoma, dorsal aspect; B—subcapitulum.

Leg chaetotaxy: $\operatorname{Tr} 1\left(v^{\prime}\right), \mathrm{Fe} 6\left(d, l^{\prime}, l^{\prime \prime}, v^{\prime}, v^{\prime \prime}\right.$, $\left.b v^{\prime \prime}\right), \operatorname{Ge} 4$ (d, l', l', k), Ti 5(2) (d, l', l', v', v", $\varphi$, $\varphi p)$, Тa 13(1) ( $p^{\prime}, p^{\prime \prime}, t c^{\prime}, t c^{\prime \prime}, f t^{\prime}, f t^{\prime \prime}, u^{\prime}, u^{\prime \prime}, a^{\prime}, a^{\prime \prime}$, $p l$ ', $p l,, v s, \omega)$. Setae $k$ of genu, $d$ of tibia and $(p)$, $(t c),(f t)$ of tarsus smooth, blunt-ended, eupathidlike; other setae sparsely barbed; seta $d$ of femur weakly blunt-ended, other setae pointed. Seta $d$ of genu distinctly longer than seta $k 19-21$. Solenidion $\omega$ 16-17, finger-shaped; solenidion $\varphi$ 9-10 baculiform, $\varphi p$ 30-35 attenuate, with rounded tip. Leg II (Fig. 3B). Leg chaetotaxy: Tr $1\left(v^{\prime}\right), \operatorname{Fe} 5(d$, l', l', v', bv'), Ge 4 (d, l', l', $k)$, Ti 5(1) (d, l', l', $\left.v^{\prime}, v^{\prime \prime}, \varphi p\right)$, Ta 9(1) ( $p^{\prime}, t c^{\prime}, t c^{\prime \prime}, u^{\prime}, u^{\prime \prime}, a^{\prime}, a^{\prime \prime}, p l$, $v s, \omega)$. Setae $k$ of genu, $d$ of tibia, $p^{\prime}$ and $t c^{\prime}$ of tarsus smooth, blunt-ended, eupathid-like, other setae weakly barbed; seta $d$ of femur weakly bluntended, other setae pointed. Solenidion $\omega$ 14-15 finger-shaped; solenidion $\varphi p$ 28-29 attenuate, with rounded tip. Seta $k$ short 9-10, more than two times shorter than setae $d$ of genu. Leg III (Fig. 4A). Leg chaetotaxy: Tr 2 ( $\left.v^{\prime}, l^{\prime}\right), \mathrm{Fe} 3\left(d, l^{\prime}, e v^{\prime}\right), \mathrm{Ge} 1(d)$, Ti 5(1) (d, l', l', $\left.v^{\prime}, v^{\prime \prime}, \varphi p\right)$, Ta 7(1) (tc', tc", $u^{\prime}$, $\left.u^{\prime \prime}, a^{\prime}, a^{\prime \prime}, v s, \omega\right)$. Solenidion $\omega$ 11-12 finger- shaped; solenidion $\varphi p$ 25-27 attenuate, with rounded tip. All setae weakly barbed; seta $d$ of femur weakly blunt-ended, other setae pointed. Leg IV (Fig. 4B). Leg chaetotaxy: Tr 1 ( $\left.v^{\prime}\right), \mathrm{Fe} 2(d$, $\left.e v^{\prime}\right)$, Ge $1(d)$, Ti 5(1) (d, l', l', v', v', $\left.\varphi p\right)$, Ta 7(1) ( $\left.t c^{\prime}, t c^{\prime \prime}, u^{\prime}, u^{\prime \prime}, a^{\prime}, a^{\prime \prime}, v s, \omega\right)$. Solenidion $\omega$ 11-12 finger-shaped; solenidion $\varphi p$ 27-29 attenuate, with rounded tip. All setae weakly barbed; seta $d$ of femur weakly blunt-ended, other setae pointed.

Material examined. Female holotype, slide № 781, Russia, Yaroslavl Region, Borok settlement, in the bark of a rotting tree stump, 22 April 1975, coll. N.N. Kuznetsov. Non type material: 5 females, Russia, Tyumen Region, Tyumen, Zatyumenskiy Park, rotting bark of Larix sibirica, 4 May 2019, coll. A. A. Khaustov; 2 females, same locality, in litter under a Larix sibirica, 26 March 2019, coll. A. A. Khaustov.

Remarks. This species was described from European Russia (Kuznetsov 1978). This is the first record of $S$. dingus in Asia. The redescription of $S$. dingus is based on specimens from Western Siberia. Comparison of Siberian specimens with 


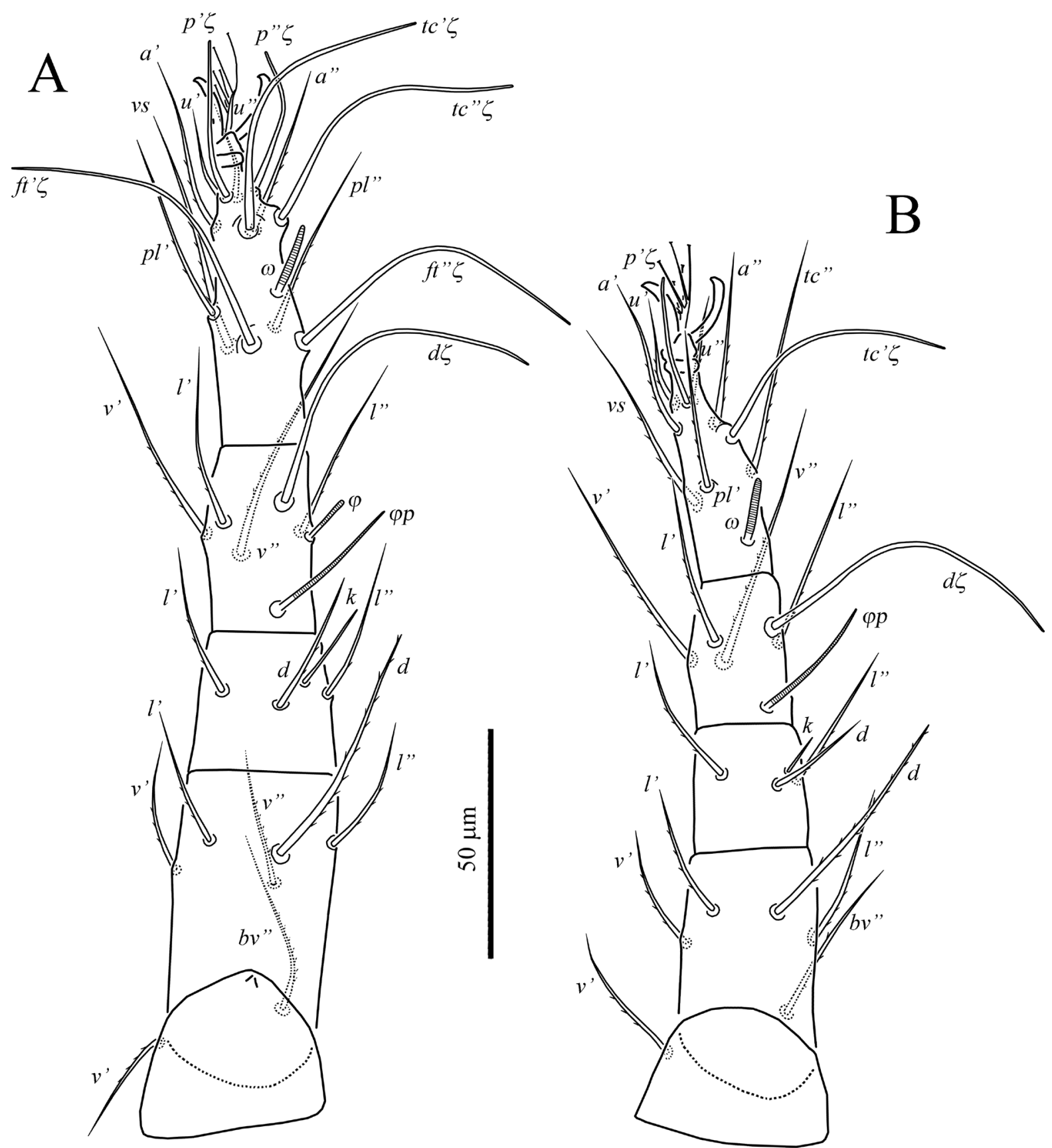

Fig. 3. Stigmaeus dingus Kuznetsov, 1978, female: A —right leg I, dorsal aspect; B—right leg II, dorsal aspect.

the holotype of $S$. dingus confirmed their conspecificity.

\section{Stigmaeus uzunolukensis Özçelik and Doğan, 2011}

(Figs. 6-14)

Stigmaeus uzunolukensis Özçelik and Doğan, 2011, 702, Figs. 1 (A-G).

Redescription. Female (Figs. 6-11). Length of idiosoma 285-290, width 180-195.
Idiosomal dorsum (Figs. 6A, 7, 11A). Central shield with two pairs of setae $c_{1}$ and $d_{1}$; median zonal and intercalary shields paired. All shields with poorly visible subcuticular reticulation and large dorsal oval dimples (Fig. 11A). Postocular bodies small, smooth. Eyes absent. Striation anterolateral to prodorsal plate without microtubercles. Setae ve, sce and $c 2$ pointed; setae $e 1, f$ and $h 1$ with distinctly widened and flattened tips bearing "crown" of barbs, other dorsal setae bluntended and sparsely barbed in distal half (Fig. 7). 


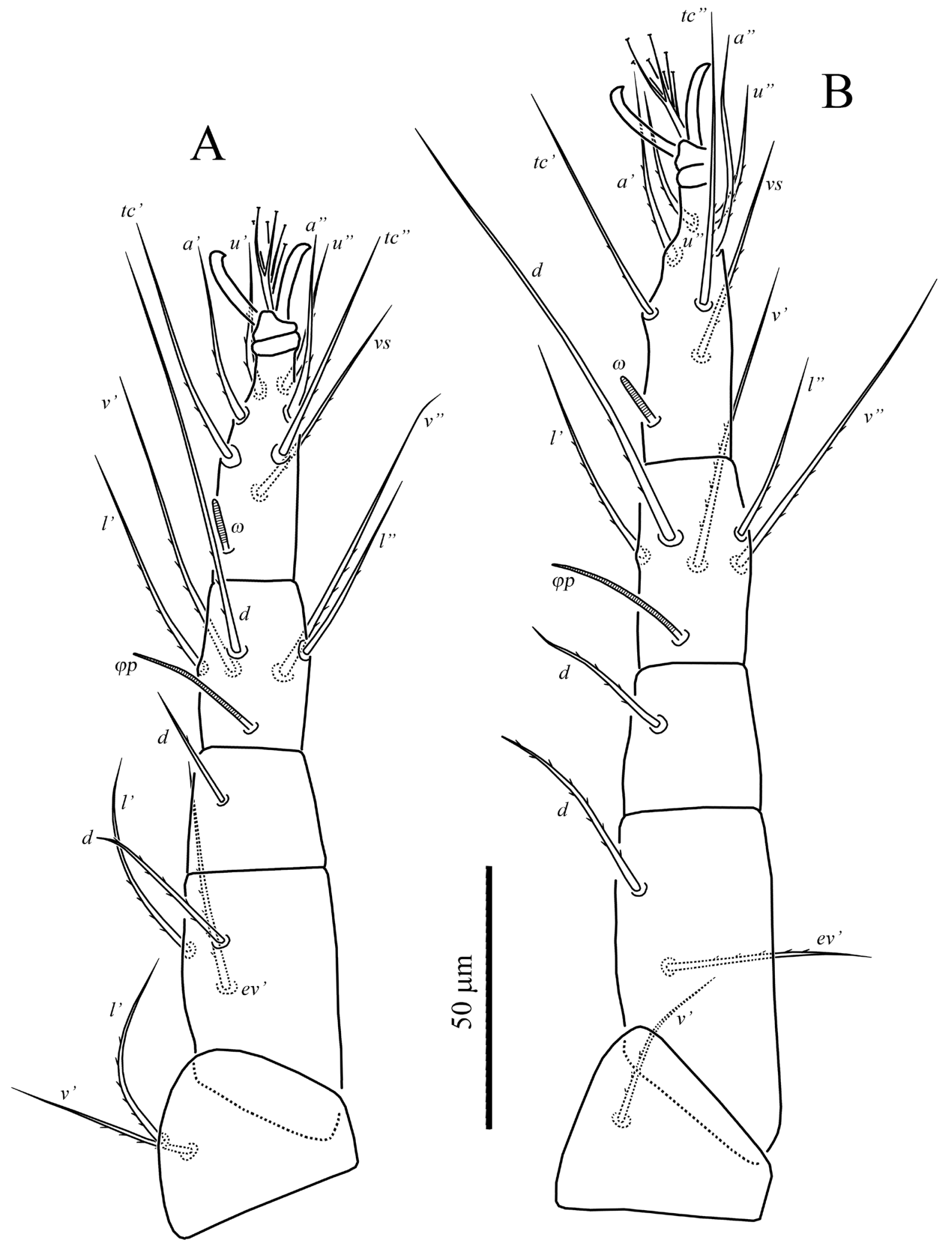

Fig. 4. Stigmaeus dingus Kuznetsov, 1978, female: A—right leg III, dorsal aspect; B—right leg IV, dorsal aspect.

Setae $p s 1$ located dorsally. Length of dorsal setae: vi 40-41, ve 70-81, sci 28-29, sce 49-53, c1 37-41, c2 52-64, d1 38-39, d2 40-43, el 35-38, e2 43-46, f 43-44, h1 41-42, h2 42-44, ps 1 30-32.
Idiosomal venter (Figs. 6B, 11B). Aggenital and endopodal plates with weak subcuticular reticulations. All ventral setae pointed and smooth. Aggenital plate with three pairs of 


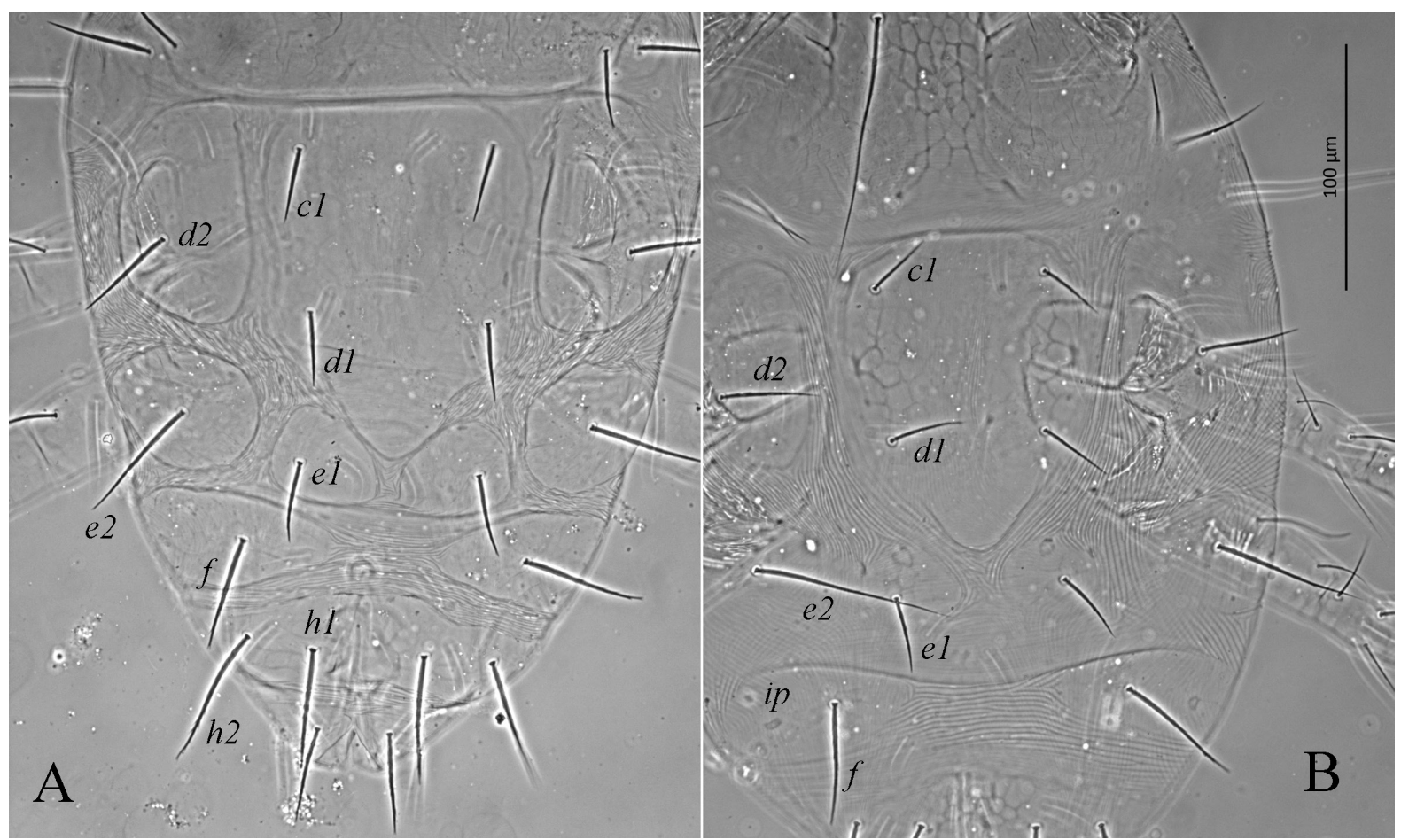

Fig. 5. Phase-contrast micrographs of Stigmaeus dingus Kuznetsov, 1978, female: A, B-dorsum of idiosoma.

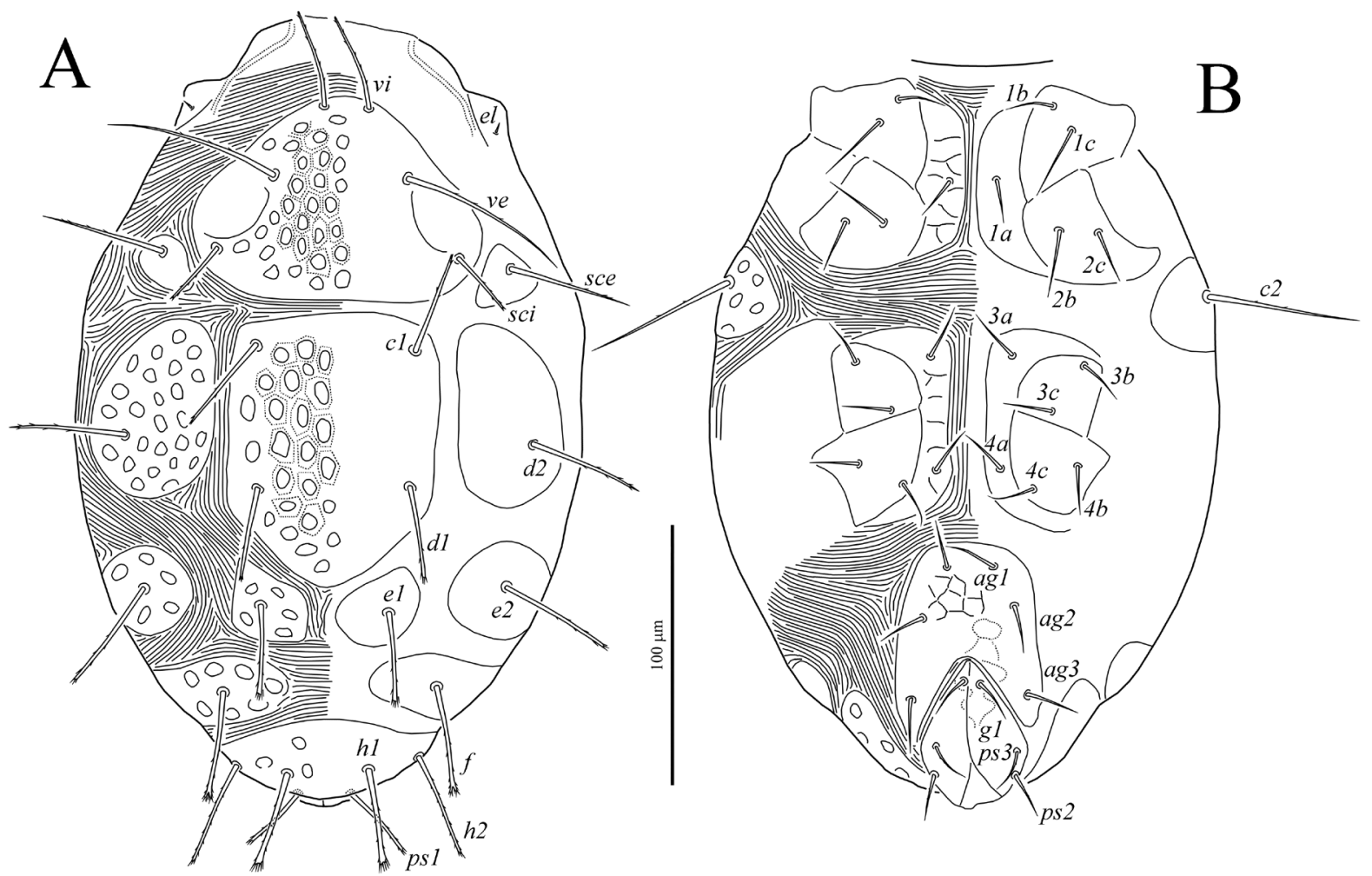

Fig. 6. Stigmaeus uzunolukensis Özçelik and Doğan, 2011, female: A—dorsum of idiosoma, B—venter of idiosoma.

aggenital setae; one pair of genital setae. Lengths of ventral setae: $1 a$ 20-22, $1 b$ 20-22, $1 c$ 29-30, $2 b$ 27-30, 2c 24-25, 3a 21-22, 3b 20-22, 3c
19-21, 4a 20-21, 4b 17-19, 4c 18-19, agl 1921, ag2 20-22, ag3 22-24, g 15-17, ps2 20-22, ps3 $17-18$. 

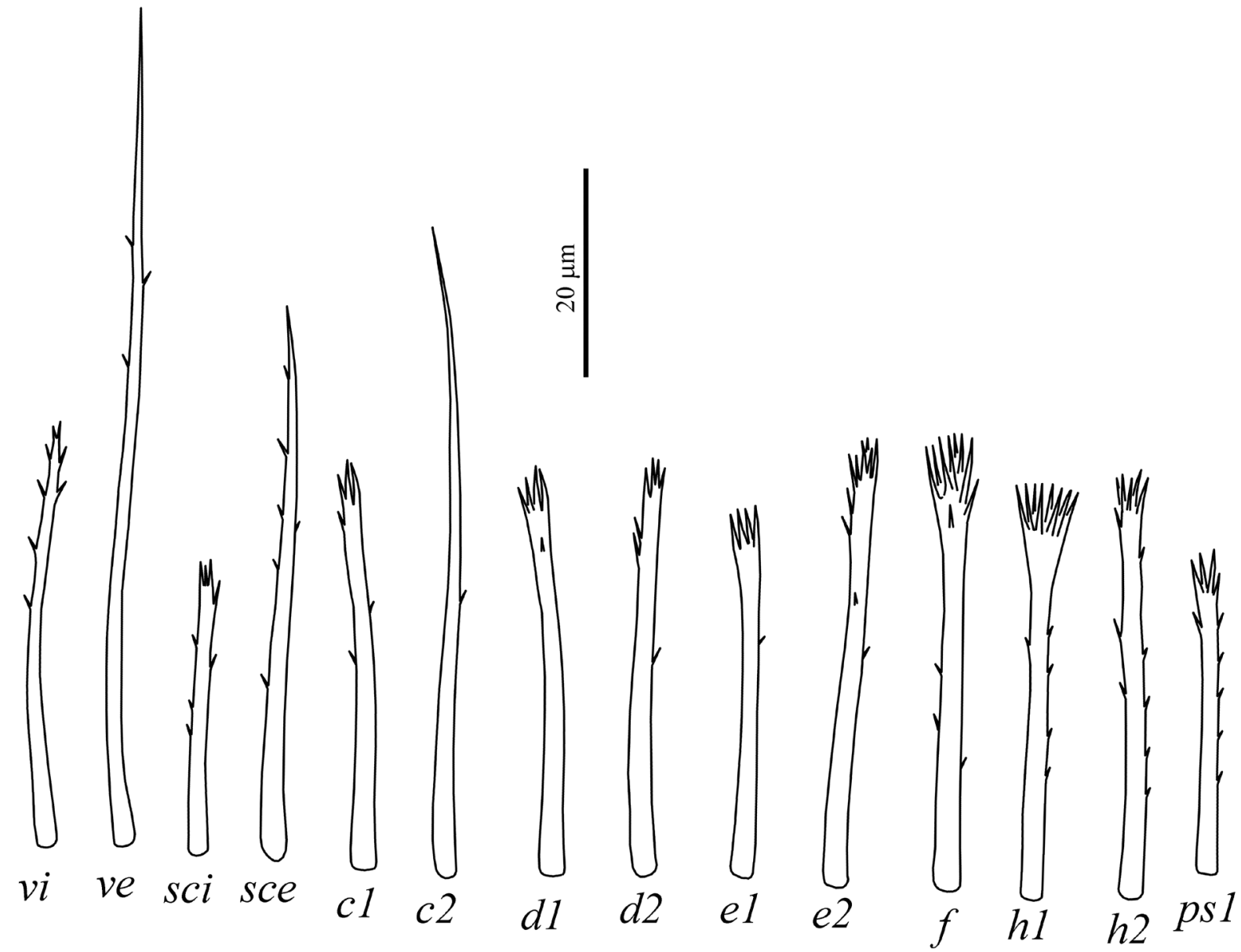

Fig. 7. Stigmaeus uzunolukensis Özçelik and Doğan, 2011, female: idiosomal setae.

Gnathosoma (Fig. 8). Tibial claw large, about as long as palptarsus. Setae $l$ ' on palpal tibia short spiniform. All setae of femur, genu and tibia pointed and weakly barbed; seta $v a$ of tarsus weakly barbed, other setae of palptarsus smooth. Number of setae on palpal segments as in S. dignus. Palpal supracoxal setae (ep) short, spiniform, located lateroventrally. Rostrum of subcapitulum (Fig. 8B) relatively long. All subcapitular setae pointed; $n$ and or 2 smooth, other subcapitular setae weakly barbed. Basal part of subcapitulum without distinct reticulation. Lengths of subcapitular setae: $m$ 22-23, $n$ 15-18, or 1 23-25, or2 19-21. Length of cheliceral stylets $55-56$.

Legs (Figs. 9, 10). All legs with one pair of well-developed claws. Empodial raylets with thin tips. Leg segments without distinct reticulation. Setation of legs as in $S$. dingus. Leg I (Fig. 9A). Coxae I posterodorsally with short spiniform leg supracoxal setae $(e l)$. Setae $k$ of genu, $d$ of tibia and $(p),(t c),(f t)$ of tarsus smooth, blunt-ended, eupathid-like; other setae pointed and sparsely barbed, sometimes $l$ " of femur and $(u)$ of tarsus smooth. Seta $d$ of genu almost two times shorter than seta $k 42-45$. Solenidion $\omega 21-24$ long, fingershaped; solenidion $\varphi$ 8-9 baculiform, $\varphi p$ 21-22 attenuate, with rounded tip. Leg II (Fig. 9B). Setae $k$ of genu, $d$ of tibia, $p^{\prime}$ and $t c$ ' of tarsus smooth, blunt-ended, eupathid-like, other setae pointed and weakly barbed. Solenidion $\omega$ 20-22 finger-shaped; solenidion $\varphi p$ 19-20 attenuate, with rounded tip. Seta $k$ short $6-7$, about twice shorter than setae $d$ of genu. Leg III (Fig. 10A). Solenidion $\omega$ 11-12 finger-shaped; solenidion $\varphi p$ 15-16 attenuate, with rounded tip. All setae pointed and weakly barbed. Leg IV (Fig. 10B). Solenidion $\omega$ 13-14 fingershaped; solenidion $\varphi p$ 15-16 attenuate, with rounded tip. All setae pointed and weakly barbed.

Male (Figs. 12-14). Length of idiosoma 250, width 160 .

Idiosomal dorsum (Fig. 12A). Central and marginal shield fused, with three pairs of setae $c 1$, $d 1$ and $d 2$; median zonal and intercalary shields paired. Prodorsal and central shields with poorly 


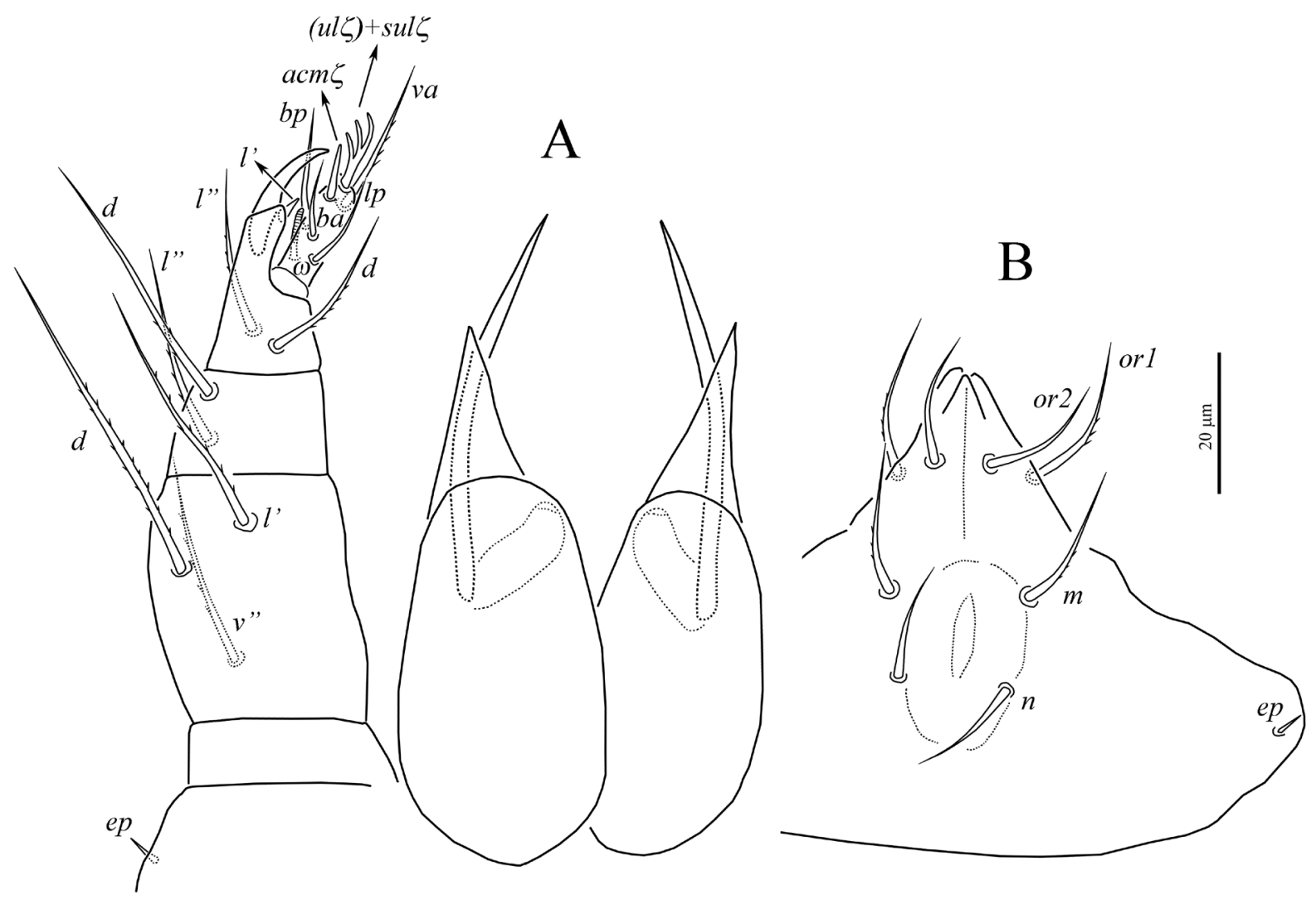

Fig. 8. Stigmaeus uzunolukensis Özçelik and Doğan, 2011, female: A—gnathosoma, dorsal aspect, B-subcapitulum.

visible subcuticular reticulation and large dorsal oval dimples. Setae ve, $c 2, h 1$, and $h 2$ pointed; other dorsal setae blunt-ended and sparsely barbed; setae $p s 1$ very short, spiniform. Aedeagus poorly sclerotized. Lengths of dorsal setae: vi 30, ve 47, sci 19, sce 33, c1 22, c2 49,d1 25, d2 30, e1 20, e2 36,f42, h1 16, h2 31,ps1 4, ps 11.

Idiosomal venter (Fig. 12B). All ventral plates without subcuticular reticulations. All ventral setae pointed and smooth. Aggenital plate with three pairs of aggenital setae; two pairs of pseudanal setae. Lengths of ventral setae: $1 a 16,1 b 19,1 c 23$, $2 b 22,2 c 19,3 a 16,3 b 15,3 c 16,4 a 17,4 b 13,4 c$ 14, ag1 14, ag2 18, ag3 17.

Gnathosoma as in female. Lengths of subcapitular setae: $m 20, n 17$, or 121 , or 216 . Length of cheliceral stylets 45 .

Legs (Figs. 13, 14). Legs as in female, except presence of well-developed male solenidia on tarsi I-IV. Leg I (Fig. 13A). Seta $d$ of genu slightly shorter than seta $k 32$. Solenidia $\omega 21$ and $\omega{ }^{\lambda}$ 32 long, finger-shaped; solenidion $\varphi 6$ baculiform, $\varphi p 19$ attenuate, with rounded tip. Leg II (Fig. 13B). Solenidia $\omega 18$ and $\omega{ }^{\Uparrow} 29$ finger-shaped; solenidion $\varphi p 17$ attenuate, with rounded tip. Seta $k$ short
6, about twice shorter than setae $d$ of genu. Leg III (Fig. 14A). Solenidia $\omega 10$ and $\omega{ }^{\lambda} 29$ fingershaped; solenidion $\varphi p 13$ attenuate, with rounded tip. Leg IV (Fig. 14B). Solenidia $\omega 11$ and $\omega{ }^{\Uparrow} 30$ finger-shaped; solenidion $\varphi p 13$ attenuate, with rounded tip.

Material examined. Seven females, 1 male, Russia, Tyumen Region, vicinities of Lake Kuchak, $57.021^{\prime} \mathrm{N}, 66.003^{\prime} \mathrm{E}$, in rotting tree stump, 26 September 2018, coll. A. A. Khaustov.

Remarks. This species was described from Turkey (Özçelik and Doğan 2011). This is the first record of S. uzunolukensis in Russia. The redescription of S. uzunolukensis is based on the specimens from Western Siberia. It coincides well with the original description of the idiosoma, especially in regards to the shape of the dorsal setae, which is quite distinctive. The original description lacks gnathosoma illustrations. Also, the descriptions and figures of legs are incomplete.

\section{Stigmaeus harsitensis Doğan, Doğan and Erman, 2017}

Stigmaeus harsitensis Doğan et al. 2017, 463, Figs. 15-23. 


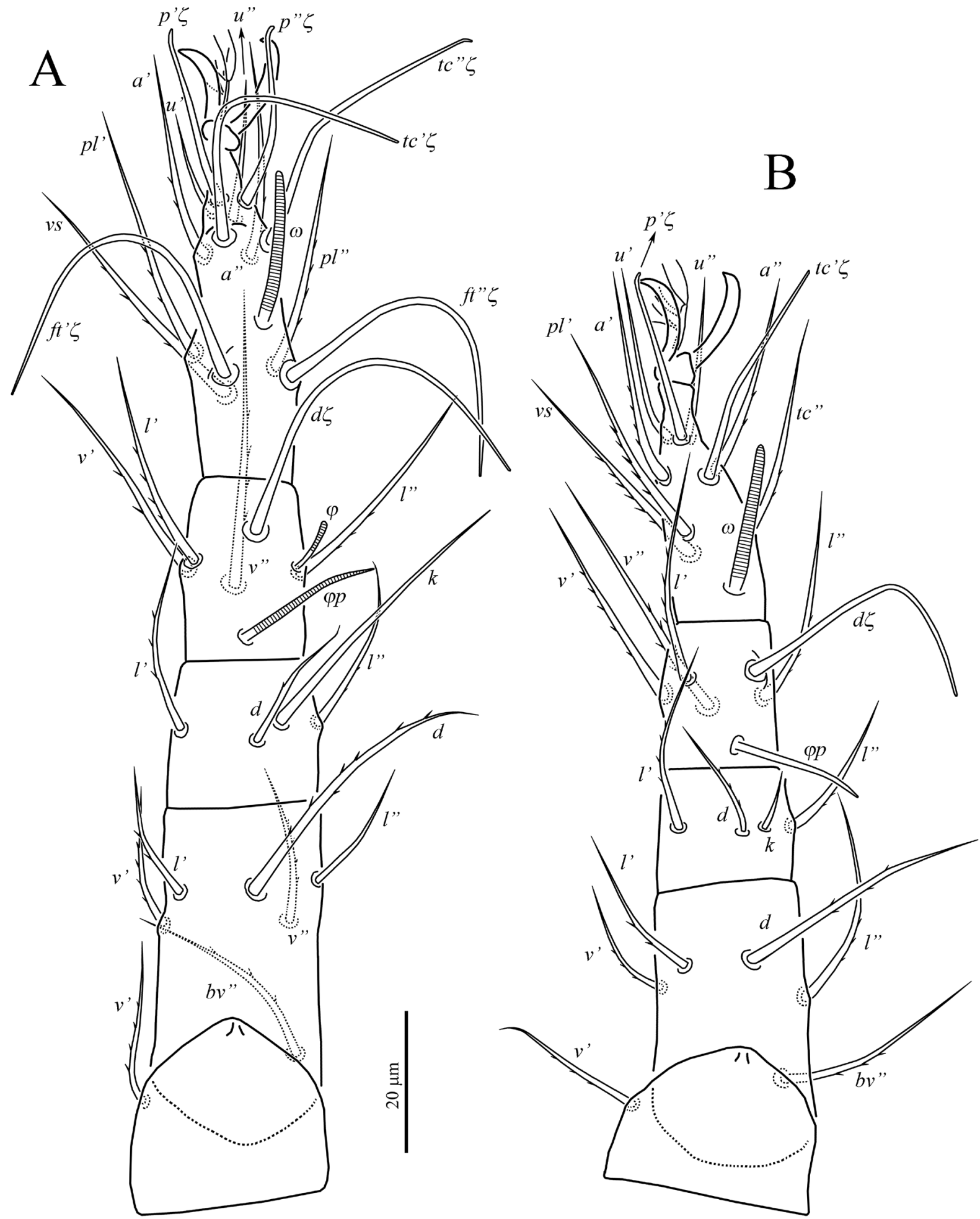

Fig. 9. Stigmaeus uzunolukensis Özçelik and Doğan, 2011, female: A—right leg I, dorsal aspect, B—right leg II, dorsal aspect.

This species was described from Turkey, from grassland soil, moss, and litter (Doğan et al. 2017). It was also recorded and redescribed from Greece (Stathakis et al. 2019). This is the first record of S. harsitensis from Russia.
Material examined. Ten females, 6 males, Russia, Kurgan Region, Zverinogolovskiy District, vicinity of the Ukrainets settlement, $54^{\circ} 24^{\prime} 11.6^{\prime \prime} \mathrm{N}$, $64^{\circ} 49^{\prime} 08.6^{\prime \prime} \mathrm{E}$, in grassland soil, 13 September 2015, coll. A. A. Khaustov. 

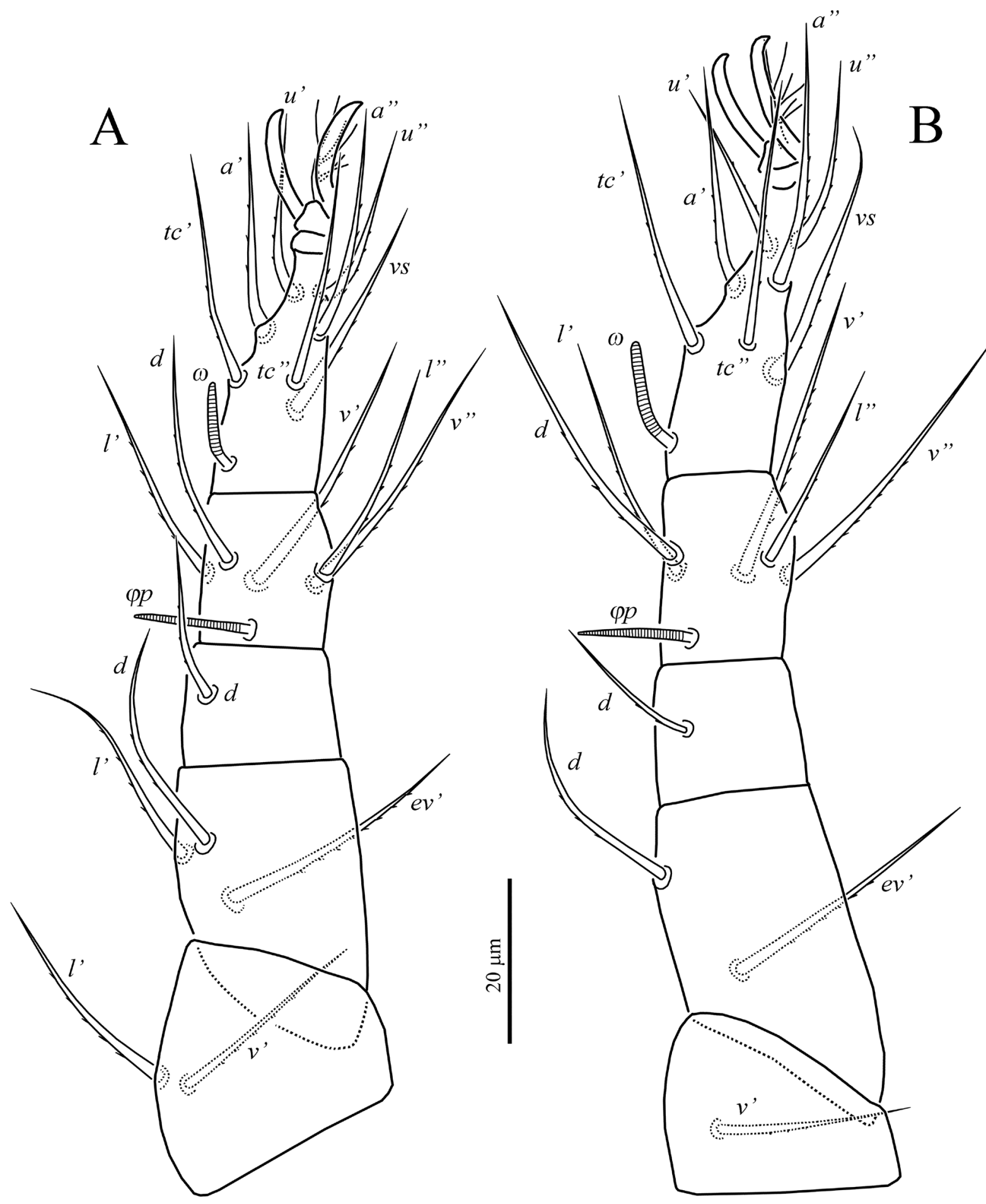

Fig. 10. Stigmaeus uzunolukensis Özçelik and Doğan, 2011, female: A—right leg III, dorsal aspect, B—right leg IV, dorsal aspect.

\section{Stigmaeus fimus Doğan, Doğan and Erman, 2017}

Stigmaeus fimus Doğan et al. 2017, 456, Figs. 6-14.

This species was described from Turkey from cow dung (Doğan et al. 2017). This is the first record of S. fimus from Russia.
Material examined. Ten females, 2 males, 1 PN, Russia: Tyumen Region, Tyumen District, vicinity of settlement Uspenka, $57^{\circ} 04^{\prime} \mathrm{N}, 65^{\circ} 04^{\prime} \mathrm{E}$, in rotting grass located in an open field on the field, 18 October 2017, coll. A.A. Khaustov. 


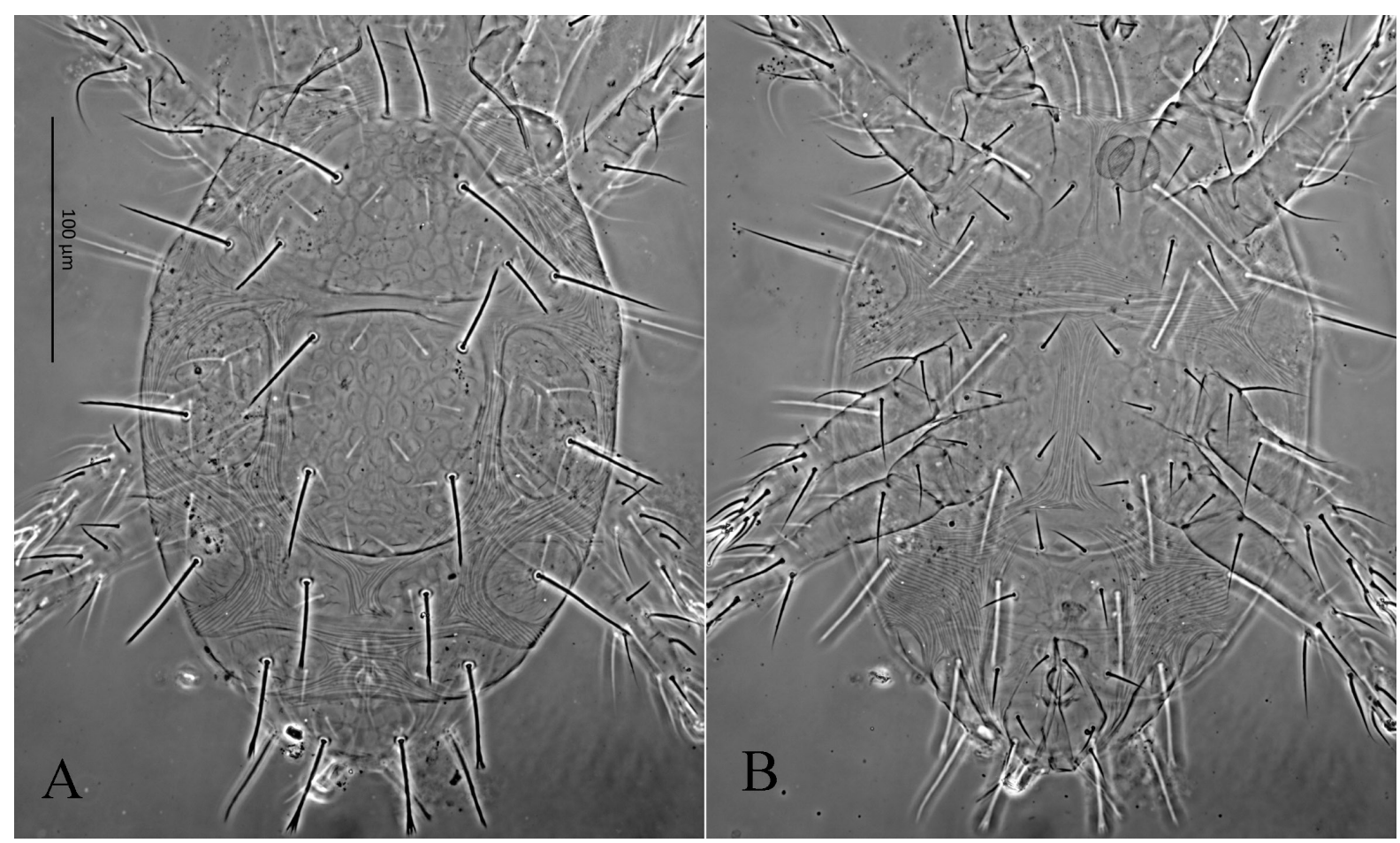

Fig. 11. Phase-contrast micrographs of Stigmaeus uzunolukensis Özçelik and Doğan, 2011, female: A—dorsum of idiosoma, B-venter of idiosoma.
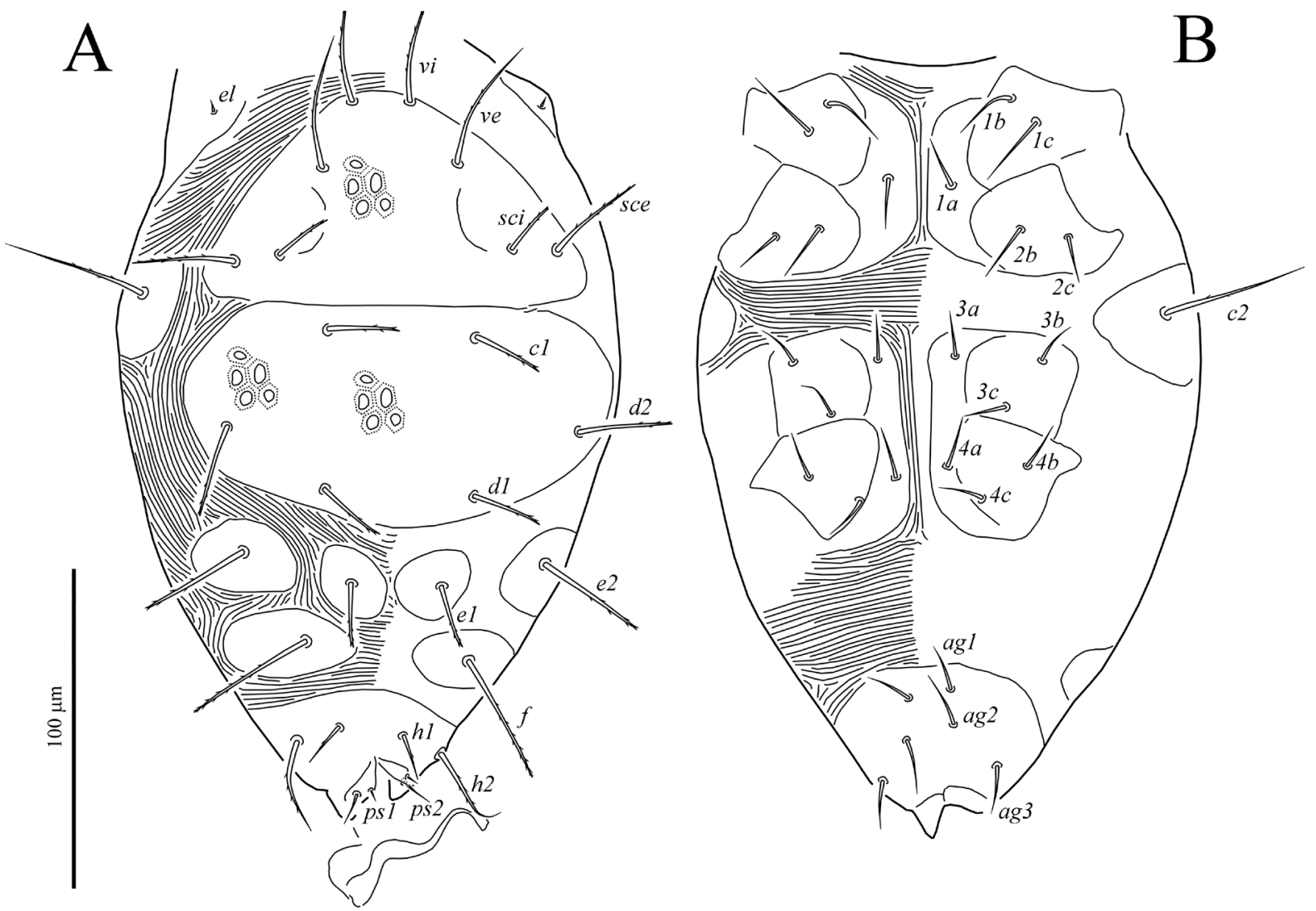

Fig. 12. Stigmaeus uzunolukensis Özçelik and Doğan, 2011, male: A—dorsum of idiosoma, B—venter of idiosoma. 


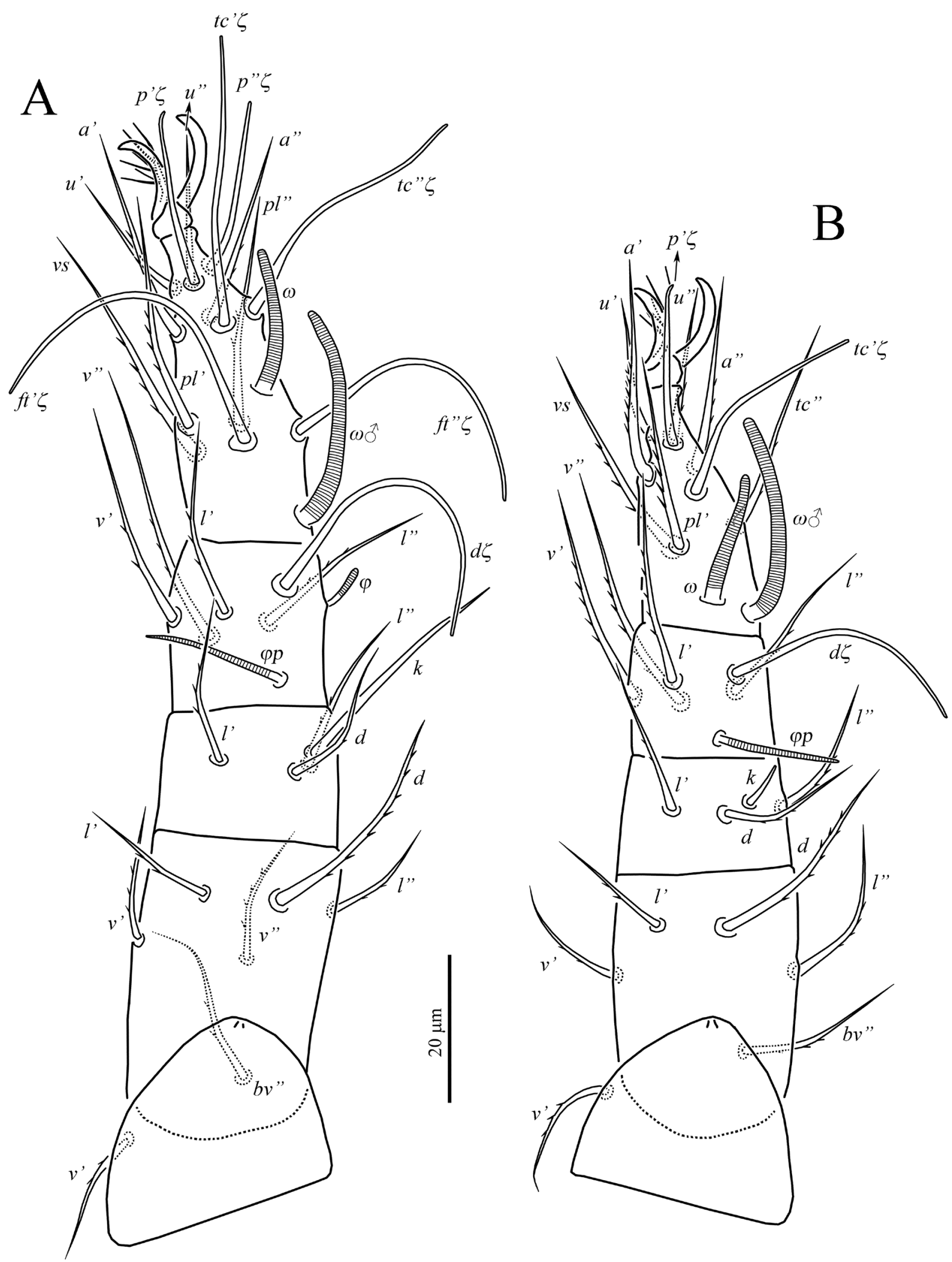

Fig. 13. Stigmaeus uzunolukensis Özçelik and Doğan, 2011, male: A—right leg I, dorsal aspect; B—right leg II, dorsal aspect. 

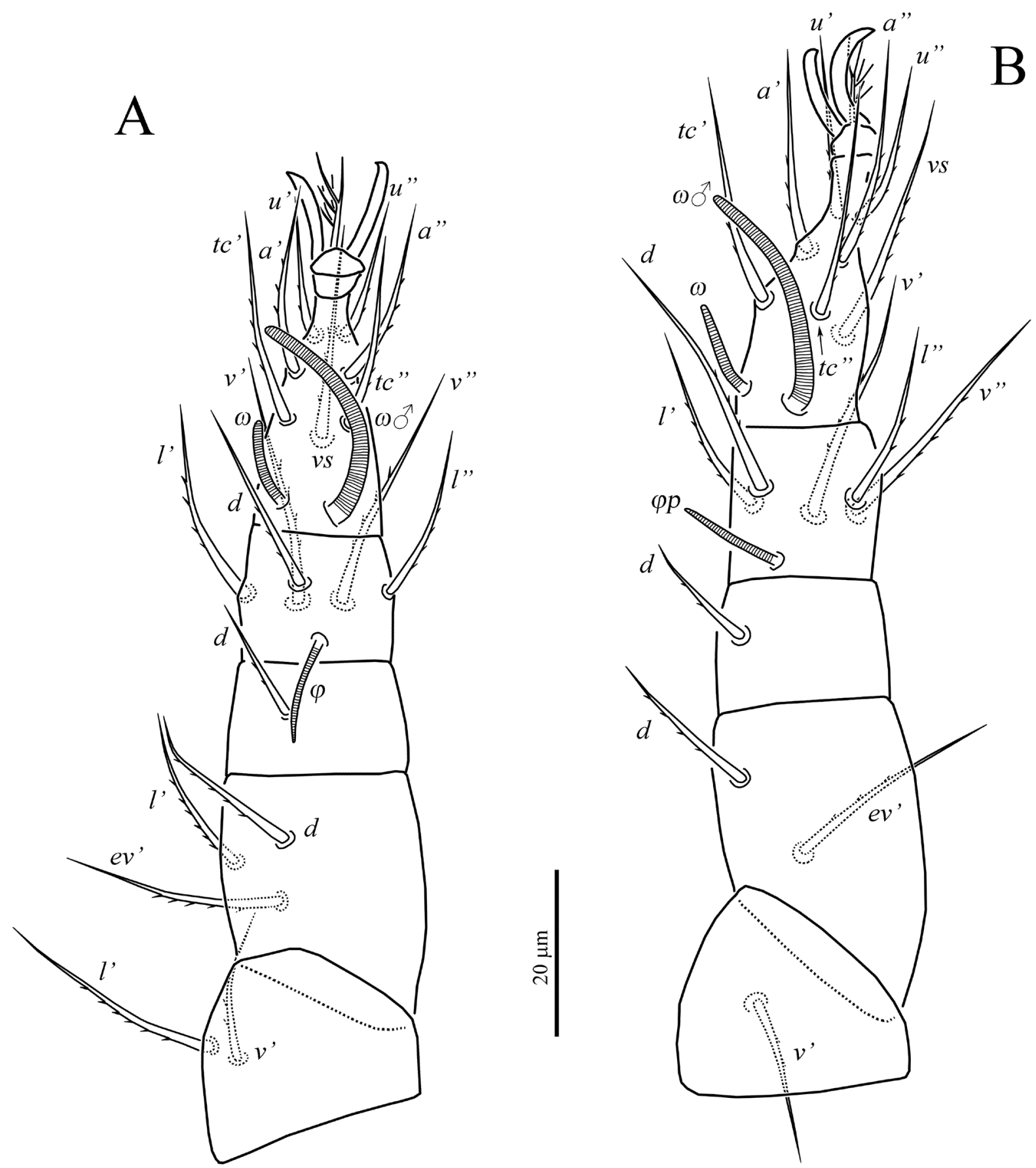

Fig. 14. Stigmaeus uzunolukensis Özçelik and Doğan, 2011, male: A—right leg III, dorsal aspect; B—right leg IV, dorsal aspect.

\section{Stigmaeus corticeus Kuznetsov and Wainstein, 1977}

Stigmaeus corticeus Kuznetsov and Wainstein, 1977, 477, Fig. 1.

This species was described from European Russia, from soil in an open field (Kuznetsov and Wainstein 1977). Khaustov and Kuznetsov (1997) reported this species from Ukraine. Faraji and Ueckermann (2006) redescribed it based on mate- rials from France. It is also known from Slovakia (Fan et al. 2016). This is the first record of S. corticeus from Asian Russia.

Material examined. Five females, Russia, Kurgan Region, Zverinogolovskiy District, vicinity of the Ukrainets settlement, $54^{\circ} 24^{\prime} 11.6^{\prime \prime} \mathrm{N}$, $64^{\circ} 49^{\prime} 08.6^{\prime \prime} \mathrm{E}$, in grassland soil, 13 September 2015, coll. A.A. Khaustov. 


\section{Stigmaeus pilatus Kuznetsov, 1978} $1, \mathrm{IV}$.

Stigmaeus pilatus Kuznetsov 1978, 690, Fig.

This species was described from Crimea, from soil (Kuznetsov 1978). It was reported from Azerbaijan, Greece, Iran, Poland, Slovakia, Spain, Turkey, Ukraine (Fan et al., 2016, Stathakis et al. 2019) and Latvia (Kuznetsov and Petrov 1984). Stathakis et al. (2019) provided the latest redescription of this species. This is the first record of $S$. pilatus from Asian Russia.

Material examined. Four females, 3 males, Russia: Tyumen Region, Berdiuzhskiy District, vicinity of Lake Solenoe, $55^{\circ} 42^{\prime} 35.0^{\prime \prime} \mathrm{N} 68^{\circ} 42^{\prime} 49.0^{\prime \prime} \mathrm{E}$, in grassland soil, 13 September 2015, coll. A.A. Khaustov.

\section{ACKNOWLEDGEMENTS}

The present research was supported by the Russian Science Foundation (grant № 20-64-47015).

\section{REFERENCES}

Doğan, S. and Doğan, S. 2020. Pülümür Vadisi'nden (Türkiye) yeni bir Stigmaeus Koch (Acari, Stigmaeidae) Türü. Acarological Studies, 2(1): 41-45. [In Turkish]

Doğan, S., Doğan, S. and Türk M.B. 2020. A new species of the genus Prostigmaeus Kuznetzov (Trombidiformes: Stigmaeidae) from Turkey. Systematic and Applied Acarology, 25 (6): 1075-1084.

Doğan, S., Doğan, S. and Erman, O. 2017. Description of five new species of the genus Stigmaeus Koch (Acari: Raphignathoidea: Stigmaeidae) from Turkey. Zootaxa, 4276(4): 451-478.

Doustaresharaf, M.M. and Bagheri, M. 2019. Ledermuelleriopsis alvatanensis sp. nov. (Acari: Stigmaeidae): a new species of stigmaeid mites from Iran. International Journal of Acarology, 45(6-7): 347-355.

Doustaresharaf, M.M., Bagheri, M. and Saber, M. 2019. Two species of stigmaeid mites (Acari: Stigmaeidae) from Iran: Eryngiopus rezaiyeiensis sp. nov. and Parastigmaeus urmiaensis sp. nov. Systematic and Applied Acarology, 24(2): 259-270.

Fan, Q.-H., Flechtmann C.H.W. and De Moraes, G.J. 2016. Annotated catalogue of Stigmaeidae (Acari: Prostigmata), with a pictorial key to genera. Zootaxa, 4176: 1-199.

Fan, Q.-H., Flechtmann C.H.W. and De Moraes, G.J. 2019. Emendations and updates to "Annotated catalogue of Stigmaeidae (Acari: Prostigmata), with a pictorial key to genera". Zootaxa, 4647(1): 88-103.
Faraji, F. and Ueckermann, E. A. 2006. A new species of Stigmaeus from Spain, redescription of S. corticeus Kuznetsov and Wainstein and a key to the European species of Stigmaeus (Stigmaeidae). Acarologia, 46: 87-93.

Gerson, U., Smiley, R.L. and Ochoa, R. 2003. Mites (Acari) for Pest Control. Blackwell Science, 540 pp.

Grandjean, F. 1939. Les segments postlarvaires de l'hysterosoma chez les oribates (Acariens). Bulletin de la Société Zoologique de France, 64: 273-284.

Grandjean, F. 1944. Observations sur les Acariens de la famille des Stigmaeidae. Archives des Sciences Physiques et Naturelles, 26: 103-131.

Grandjean, F. 1946. Au sujet de l'organe de Claparède, des eupathides multiples et des taenidies mandibulaires chez les Acariens actinochitineux. Archives des Sciences Physiques et Naturelles, 28: 63-87.

Kethley, J.B. 1990. Acarina: Prostigmata (Actinedida). In: D. L. Dindal (Ed.). Soil Biology Guide. Wiley, New York, pp. 667-756.

Khan, B. S., Afzal, M., Bashir, M.H., Farooq, M. and Ghaffar, A. 2019. Description of a new predatory mite species of the genus pseudostigmaeus (pseudo stigmaeus solanumus) acari: prostigmata: stigmaeide from Pakistan. Advances in Plant and Agriculture Research, 9(1): 202-204.

Khaustov A.A. 2015. New species and new records of mites of the genus Stigmaeus (Acari: Prostigmata: Stigmaeidae) from Western Siberia with redescription of S. livschitzi Kuznetsov, 1977. Systematic and Applied Acarology, 20 (6): 681-692.

Khaustov, A.A. 2016. Two new species and a new record of mites of the family Stigmaeidae (Acari: Prostigmata) collected from mosses in Russia. Acarologia, 56(3): 321-339.

Khaustov, A.A. and Abramov, V.V. 2017. A new species and a new record of raphignathoid mites (Acari: Raphignathoidea: Camerobiidae, Stigmaeidae) occurring in the galleries of bark beetles (Coleoptera: Curculionidae: Scolytinae) from Russia. Systematic and Applied Acarology, 22(9): 1385-1398.

Khaustov, A. A. and Kuznetsov, N. N. 1997. Raphignathoid mites (Acariformes: Raphignathoidea) of North-Eastern Ukraine, with the description of a new species of the genus Caligonella. Vestnik Zoologii, 31: 80-83. [In Russian]

Kuznetsov, N.N. 1978. Revision of the genus Stigmaeus (Acariformes, Stigmaeidae). Zoologicheskiy Zhurnal, 57: 682-694. [In Russian]

Kuznetsov, N.N. and Petrov, V.M. 1984. Predacious mites of the Baltic region (Parasitiformes: Phytoseiidae, Acariformes: Prostigmata). Riga, Zinatne. 142 pp. [In Russian] 
Kuznetsov, N.N. and Wainstein, B.A. 1977. New species of the family Stigmaeidae (Acariformes) in the fauna of the USSR. Zoologicheskiy Zhurnal, 56: 476-479. [In Russian]

Özçelik, S. and Doğan, S. 2011. A systematic investigation on Stigmaeid mites (Acari: Stigmaeidae) of Uzunoluk forest (Erzurum, Turkey). Turkish Journal of Entomology, 35: 699-719. [In Turkish]
Stathakis, T.I., Kapaxidi E.V. and Papadoulis, G.Th. 2019. The genus Stigmaeus Koch (Acari: Stigmaeidae) from Greece. Systematic and Applied Acarology, 24(11): 2010-2093.

Summers, F.M. 1962. The genus Stigmaeus (Acarina: Stigmaeidae). Hilgardia, 33: 491-537. 